\title{
SURFACE DEFORMATIONS NEAR THE BAIKAL-AMUR RAILWAY FROM DIFFERENTIAL SAR INTERFEROMETRY DATA
}

\author{
M. A. Lebedeva1, V. A. Sankov¹, 2, A. I. Zakharov, L. N. Zakharova3 \\ ${ }^{1}$ Institute of the Earth's Crust, Siberian Branch of RAS, Irkutsk, Russia \\ ${ }^{2}$ Irkutsk State University, Irkutsk, Russia \\ ${ }^{3}$ Fryazino Branch of V.A. Kotel'nikov Institute of Radioengineering and Electronics of RAS, Fryazino, Russia
}

\begin{abstract}
This paper presents SAR interferometric data obtained in the study of surface deformations of different origin within the Upper Angara-Muya interbasin link of the northeastern segment of the Baikal rift system, Russia. Differential SAR interferometry using images with small perpendicular baselines was applied in this geodynamical study. The potential of using ENVISAT/ASAR and ALOS/PALSAR data is discussed. New geodynamical data on recent strain patterns were obtained. The endogenous linear-localized and areal deformations were revealed in the influence zone of the active Muyakan fault. The origin of these deformations is discussed. The landslide that negatively affects the Baikal-Amur railway facilities is also studied. The use of SAR data for detailed study and monitoring of the landslide is discussed. It is confirmed that natural hazard in the study area is growing due to the ongoing landsliding.
\end{abstract}

Key words: differential SAR interferometry; endogenous deformations; landslide; natural hazard

Recommended by S.I. Sherman

For citation: Lebedeva M.A., Sankov V.A., Zakharov A.I., Zakharova L.N. 2016. Surface deformations near the Baikal-Amur railway from differential SAR interferometry data. Geodynamics \& Tectonophysics 7 (2), 315-328. doi:10.5800/GT-2016-7-2-0209.

\section{ДЕФОРМАЦИИ ЗЕМНОЙ ПОВЕРХНОСТИ ВБЛИЗИ ТРАССЫ БАЙКАЛО- АМУРСКОЙ ЖЕЛЕЗНОДОРОЖНОЙ МАГИСТРАЛИ ПО ДАННЫМ ДИФФЕРЕНЦИАЛЬНОЙ РСА ИНТЕРФЕРОМЕТРИИ}

\author{
М. А. Лебедева1, В. А. Саньков, 2, А. И. Захаровㄹ, Л. Н. Захарова \\ ${ }^{1}$ Институт земной коры СО РАН, Иркутск, Россия \\ ${ }^{2}$ Иркутский государственный университет, Иркутск, Россия \\ 3 Фрязинский филиал Института радиотехники и электроники им. В.А. Котельникова РАН, \\ Фрязино, Россия
}

Аннотация: Введение. Первые разработки принципов интерферометрии с применением радара с синтезированной апертурой (РСA), установленного на борту космических спутников, проводились в восьмидесятых годах прошлого столетия. С тех пор метод РСА интерферометрии успешно используется во всем мире для исследований деформаций земной поверхности различного генезиса. Мы применяем данный метод для выявления опасных деформаций вблизи одного из участков трассы Байкало-Амурской магистрали ВосточноСибирской железной дороги (БАМ ВСЖД). Сложная геодинамическая обстановка района, обусловленная современными деформациями земной коры, влияет на инженерно-сейсмогеологические особенности трассы.

Методика. Суть метода дифференциальной РСА интерферометрии состоит в обработке пар радарных изображений, снятых в два разных момента времени, между которыми произошла деформация. Разность фаз сигналов, полученных при съемке, отображается с помощью интерферограмм. Монохромная или цветная шкала интерферограммы характеризует величину и направление сдвига, произошедшего при деформации. В 
нашем исследовании применялись данные с двух спутников: ENVISAT (инструмент ASAR, С-диапазон) и ALOS (инструмент PALSAR, L-диапазон). При длине волны 5.6 см (С-диапазон) фазовый набег $2 \pi$ на интерферограмме порождается изменением дальности по направлению к спутнику на 2.8 см; при длине волны 23.6 см (L-диапазон) - на 11.8 cм. Разности дальностей в направлении на точку съемки пересчитываются в истинные изменения положения земной поверхности. Преимуществом метода перед другими способами измерения деформаций является высокоточное измерение смещений земной поверхности по всей площади объекта. Существуют ограничения метода, такие, как временная декорреляция, происходящая из-за изменения радиофизических свойств поверхности, и влияние атмосферных и ионосферных явлений. Ограничения и методы их преодоления детально описаны в [Hanssen, 2001].

Геодинамическая обстановка. Район наших исследований находится в пределах Верхнеангарско-Муйской междувпадинной перемычки северо-восточного сегмента Байкальской рифтовой системы, в зоне динамического влияния Муяканского и Перевального разломов (рис. 1). Высокий уровень сейсмичности подтверждает современную геодинамическую активность района исследований. Эпицентральное поле с магнитудами землетрясений $2.6<\mathrm{ML}<6.2$ наблюдается с 1962 по 2012 гг. (по данным Байкальского филиала Геофизической службы Сибирского отделения Российской академии наук (рис. 2)).

В исследуемом районе трасса БАМ проходит вдоль Муяканской структуры почти на всем ее протяжении и пересекает отдельные ее дислокации. Таким образом, инженерно-сейсмогеологические условия трассы на этом участке неблагоприятны [Solonenko, Mandelbaum, 1985]. Региональный Перевальный разлом простирается в северо-западном направлении. Выраженность и влияние разлома на геодинамическую обстановку на разных его отрезках различна. На исследуемом участке разлом проявлен в поле силы тяжести в виде гравитационной ступени небольшой интенсивности [San'kov et al., 1991].

Интерпретация результатов дифференциальной РСА интерферометрии. Нами произведена интерферометрическая обработка снимков ENVISAT и ALOS/PALSAR. Из-за сильной заболоченности долин и расчлененного рельефа на всех интерферограммах по снимкам ENVISAT велико влияние временной декорреляции. Однако, несмотря на это, на одних и тех же участках на трех парах снимков (13.01.2004-08.03.2005, 16.05.2004-18.09.2005 и 17.02.2004-17.01.2006) обнаружены четыре области высокой когерентности. Для анализа выбрана пара с базой интерферометра, равной 3 м (13.01.2004-08.03.2005) (рис. 3). При такой базе влияние рельефа на интерферометрическую разность фаз исчезающе мало.

В зоне динамического влияния Муяканского разлома по данным ENVISAT обнаружены два типа эндогенных деформаций, которые можно определить как тектонические - линейно локализованные и площадные.

Линейно локализованные деформации приурочены непосредственно к зоне сместителя разлома (рис. 3), прослеживающегося в основании уступа Муяканского хребта. Рассмотрение размеров аномалий, их протяженности и характера пространственного распределения позволяет исключить экзогенную природу деформаций. Сейсмическая активность зоны разлома в течение 2004-2006 гг. весьма незначительна. Следовательно, мы не можем объяснить генезис этих деформаций накоплением и реализацией упругих напряжений в виде сейсмических событий. Одним из видов деформаций, фиксируемых геодезическими методами в зонах активных разломов, как в подвижных областях, так и на платформах, являются параметрические деформации, впервые выделенные и описанные Ю.О. Кузьминым и называемые им суперинтенсивными [Kuzmin, 2013]. Скорости параметрических деформаций достигают больших величин - до $10^{-5}$. Чаще всего, они не сопровождаются сейсмичностью и локализуются непосредственно в зонах разломов. Автор связывает происхождение этих деформаций с изменениями параметров среды внутри зоны разлома, вблизи ее главного сместителя.

Площадные деформации, обнаруженные вблизи окончания Муяканского разлома (рис. 3) на СВ замыкании Муяканской впадины и в западном борту Улан-Макитской впадины, также не могут быть прямо объяснены сейсмогенными движениями. Картина распределения площадных деформаций соответствует распределению напряжений на окончании левостороннего сдвига в упругой среде [Osokina, 2010]. На восточном окончании северного крыла разлома располагается область растяжения и фиксируется относительное опускание земной поверхности, а на юго-восточной части разлома располагается область сжатия, где фиксируется относительное поднятие земной поверхности. Эти данные согласуются с данными геодинамических исследований [San'kov et al., 2000], по которым Муяканский разлом наряду с вертикальной имеет левостороннюю сдвиговую компоненту смещений.

Наряду с деформациями эндогенной природы, в зонах активных разломов Верхнеангарско-Муйской междувпадинной перемычки нами были обнаружены экзогенные деформации. На участке Байкало-Амурской железнодорожной магистрали в нескольких километрах от Северо-Муйского тоннеля (ст. Казанкан, п. Северомуйск, координаты $56.1 \mathrm{~N} 113.8 \mathrm{E}$ ) с начала 90-х годов прошлого столетия развивается оползневой процесс. Согласно данным нивелирования и геодезических GPS-измерений, проведенных на железной дороге в $2002-$ 2003 годах «Иркутскжелдорпроектом», железнодорожное полотно сдвигалось в зоне действия оползня, вдоль склона со скоростью до 2 см/мес. Развитие оползня приводит к риску разрушения железнодорожного пути и крушения поездов. Происхождение оползня связывается исследователями с процессом деградации многолетнемерзлых пород и подрезанием склона дорогой, а также чрезмерной нагрузкой на склон [Trzhtsinsky et al., 2004]. Нельзя также недооценивать влияние уровня сейсмической и тектонической активности района на разрушение пород и развитие оползней, поскольку Казанканский оползень находится в зоне влияния сейсмически активных Муяканского и Перевального разломов.

Для изучения оползневого процесса в районе ст. Казанкан мы использовали снимки с восходящего витка ALOS/PALSAR. Несмотря на зимнее время съемки и разницу между съемками в два года, хорошую корреляцию и результаты показала пара радарных снимков ALOS/PALSAR, снятых 17.01.2009 и 12.01.2007. Местоположения деформаций, наблюдаемых на интерферограммах, точно совпадают с расположением мостов (рис. 4 , 5, 6), где по данным предыдущих исследований [Trzhtsinsky et al., 2004] обнаружены значительные подвижки. У второго и третьего моста, ниже железнодорожного полотна, обнаруживаются области, испытывающие воздымание, что, по-видимому, связано с характером развития оползня. Модель развития оползня по геологиче- 
ским данным описывается как выдавливание по цилиндрической плоскости скольжения с отрицательным знаком смещения в области цирка и положительным - во фронтальной части [Trzhtsinsky et al., 2004].

На исследуемой интерферограмме наибольшее изменение дальности наблюдается ниже железнодорожных путей у второго моста. За двухлетний период, прошедший между измерениями, изменение дальности по направлению от поверхности к радару составило 6 см. Кроме того, вблизи мостов наблюдаются области с опусканием земной поверхности, связанные, по-видимому, с процессами солифлюкции. По данным РСА интерферометрии уточнено место положения оползневого цирка между вторым и третьим мостом (рис. 6). Ранее, вследствие недостатка данных, положение этого цирка отмечалось ниже по склону. Выявлено распространение процесса оползания, происходящее на склоне между первым и вторым мостом, которое не фиксировалось ранее. В будущем возможно объединение цирков и, как следствие, усиление оползневого процесса. Из полученных данных можно сделать вывод о том, что проведенные мероприятия по укреплению склона и железнодорожной насыпи не привели к остановке оползневого процесса, что говорит об острой необходимости продолжения укрепительных работ и принятия мер по изменению трассы на данном участке магистрали.

Заключение. Таким образом, исследование деформаций в районе Верхнеангарско-Муйской междувпадинной перемычки северо-восточного сегмента Байкальской рифтовой системы с применением метода дифференциальной РСА интерферометрии позволило получить новые данные о характере современных смещений земной поверхности различного происхождения. В зоне динамического влияния Муяканского разлома обнаружены два типа деформаций, которые можно определить как тектонические линейно локализованные и площадные. Наблюдаемые деформации, находящиеся непосредственно в зоне разлома, можно отнести к параметрическим, связанным с изменением состояния среды в зоне разлома. Картина распределения площадных деформаций соответствует распределению напряжений на окончании левостороннего сдвига в упругой среде.

Первые PCA-исследования, проведенные в районе п. Северомуйск, показали, что снимки ALOS/PALSAR применимы для детального изучения оползневого процесса, происходящего в районе ст. Казанкан БАМ ВСЖД. Оползневой процесс продолжает свое развитие, несмотря на проведенные укрепления. В настоящее время происходит объединение цирков на участке между первым и вторым мостом, что может привести к усилению процесса.

Таким образом, деформации в зоне Муяканского разлома могут представлять опасность для линейных сооружений Байкало-Амурской магистрали. Метод РСА интерферометрии имеет большой потенциал как для изучения уже произошедших событий в районе исследований, так и для мониторинга развивающихся процессов. В настоящее время PCA ALOS/PALSAR закончил свою работу на орбите, однако с 2014 года Японским аэрокосмическим агентством JAXA запущены новые усовершенствованные спутники РСA миссии ALOS2/PALSAR2, работающие на той же длине волны L-диапазона. Мы планируем продолжить наши исследования с использованием новых данных.

Ключевые слова: дифференциальная РСА интерферометрия; эндогенные деформации; оползень; природная опасность

\section{INTRODUCTION}

Synthetic aperture radar interferometry (InSAR) technique is implemented for collection and analysis of space-borne radar data since 1980s [Gabriel, Goldstein, 1988; Gabriel et al., 1989]. Regular revisits of satellites (e.g., ERS-1, ERS-2, ENVISAT, ALOS, RADARSAT, TerraSAR-X) over the same point on the Earth surface allow examination of time series of SAR images and processing the pairs with various time intervals and look directions. In particular, differential InSAR (DINSAR) is widely used for detectingon and estimating the surface deformations of different origin [Goldstein et al., 1993; Peltzer et al., 1994; Sandwell et al., 2008; Stramondo et al., 2011]. We have studied a potential natural hazard near a sections of the Baikal-Amur Railway, that is a branch of the East Siberian Railway (BAM ESR). For this purpose, we use DINSAR processing of the time series of SAR images for 2004-2011. The geodynamic situation in the study area is complex due to crustal deformations, which impact is negative for the railway engineering conditions.

The first section of the paper provides a brief description of the interferometric technique and a list of SAR images. The geodynamic setting of the study area is described in the second section.

The third section presents the interferometric data processing results and discusses endogenous and exogenous deformation related to the Muyakan fault and the Kazankan landslide, respectively.

\section{TECHNIQUE}

The key concept in SAR interferometry is an interferogram that gives a phase difference image between two SAR data acquisitions. In the repeat-pass interferometry, the displacements of the mapped surface between the observation dates yield an additional phase difference component that, after some processing 
steps, can be recalculated into a value of surface shift projection in the line of sight (LOS) direction. Using the additional information about the study object (e.g., motion along the slopes or vertical displacements in fault zones), one can estimate the real range of displacements.

Interferometric processing in our study was implemented using SARscape software package and FIRE RAS in-house software. DINSAR processing is usually staged as follows:

- SAR images coregistration,

- Complex interferogram calculation,

- Interferogram flattening and unwrapping,

- Displacement calculation,

- Visualization (including geocoding, matching to the different layers etc.).

In our study, the coregistration stage was implemented using a standard two-steps procedure that includes the coarse shifts estimations from orbital parameters and subsequent crosscorrelation of the images. Additional tie-points method was used also, but yielded no significant optimization of the interferogram quality. For a coregistered pair of SAR images, complex interferogram calculation is the simplest formal stage. Interferogram flattening was carried out as follows: (1) subtraction of the DEM created from PALSAR scenes, (2) SRTM (Shuttle Radar Topography Mission) digital elevation model subtraction by SARscape software, and (3) using an extremely short perpendicular baseline pair by FIRE RAS in-house software. Surface displacements were calculated only as a LOS projection, and true deformation orientations were discussed for each case. For clarity, the interferograms were supplemented with faults schemes and SAR amplitude images. The following specific processing details are also noteworthy:

- Interferograms filtering (Goldstein's algorithm);

- Phase unwrapping method (minimal cost flow).

We used the data from ENVISAT/ASAR (C-band) launched by the European Space Agency, and ALOS/ PASAR (L-band) launched by the Japan Aerospace Exploration Agency. According to the interferometric background [Cumming, Wong, 2005], the phase difference of $2 \pi$ observed in a radar interferogram corresponds to the difference of half wavelength in slant ranges from the satellite position to the point on the earth surface. This value is equal to $2.8 \mathrm{~cm}$ for C-band ENVISAT ASAR interferograms and $11.8 \mathrm{~cm}$ for L-band PALSAR interferograms. Thus, the technique allows detecting centimeter displacements on the surface. At the same time, the shifted surface area (e.g., seismogenic rupture or considerable active fault creep) can amount to dozens of quadratic kilometers. The limitations of this method include temporal decorrelation due to changes in radio-physical characteristics of the surface, and the influence of atmospheric and iono- spheric phenomena [Hanssen, 2001; Massonnet, Rabaute, 1993; Franceschetti, Lanari, 1999; Elachi, van Zyl, 2006].

\section{GEODYNAMIC SETTING}

The study area is located within the Upper AngaraMuya interbasin link in the northeastern segment of the Baikal rift system (Fig. 1). The latter is represented by a series of en echelon half grabens bordered by wellexpressed normal faults. In general, the system of the NE-oriented faults shows a typical left-lateral strikeslip structure of lithospheric scale. The Miocene-Quarternary sediments fill the basins, and ProterozoicPaleozoic metamorphic and magmatic rocks compose the rift basement. The epicenter field of the $2.6<\mathrm{M} l<6.2$ earthquakes for 1962-2012 is mapped using the database of the Baikal Division of Geophysical Survey, Siberian Branch of the Russian Academy of Sciences (Fig. 2). Currently, the Upper Angara - Muya interbasin link is one of the most seismically active areas in the Baikal rift system [Soloviev, 1985; Déverchère et al., 1993].

The objects of our study are located in the dynamic influence zone of the Muyakan and Perevalny faults (see Fig. 1). The Muyakan fault extends northeastward and strikes along the southeastern border of Muyakan basin. The en echelon fault scarps often show triangular basal facets and seismogenic paleo ruptures that are indicative of the Late Cenozoic and Holocene fault activity associated with the left-lateral oblique slip downthrown on its northwestern side. The Cenozoic amplitude of horizontal displacement is estimated at $1000 \mathrm{~m}$, and vertical displacement amplitudes range from 800 to $1300 \mathrm{~m}$ [Sherman et al., 1980].

The cumulative coseismic displacements along fresh Holocene fault scarps (less than $12.0 \mathrm{Kyr}$ ) occurred at vertical throw rates of $0.7-0.8 \mathrm{~mm} / \mathrm{yr}$, according to the field observations [San'kov et al., 2000]), or 0.8-1.0 $\mathrm{mm} / \mathrm{yr}$, as shown by the theoretical calculations based on the relationship between the basal facet height and the basal facet surface slope [Petit et al., 2009]. In some segments, the Holocene horizontal displacements about $5 \mathrm{~m}$ of amplitude are clearly visible [HoudryLémont, 1994].

The dynamic influence zone of the fault includes the Muyakan basin and its northern-side structures and ranges in width from 7.5 and $10 \mathrm{~km}$. Unlike the steep southern side of the basin, its northern side is more gentle and step-like. The displacement amplitude along some of the faults decreases gradually to the north of the basin axis. In the northern side of the basin, the Muyakan fault zone is represented by a complex of the NE- and ENE-trending secondary faults that are mainly reported as the left-lateral strike-slip faults with 


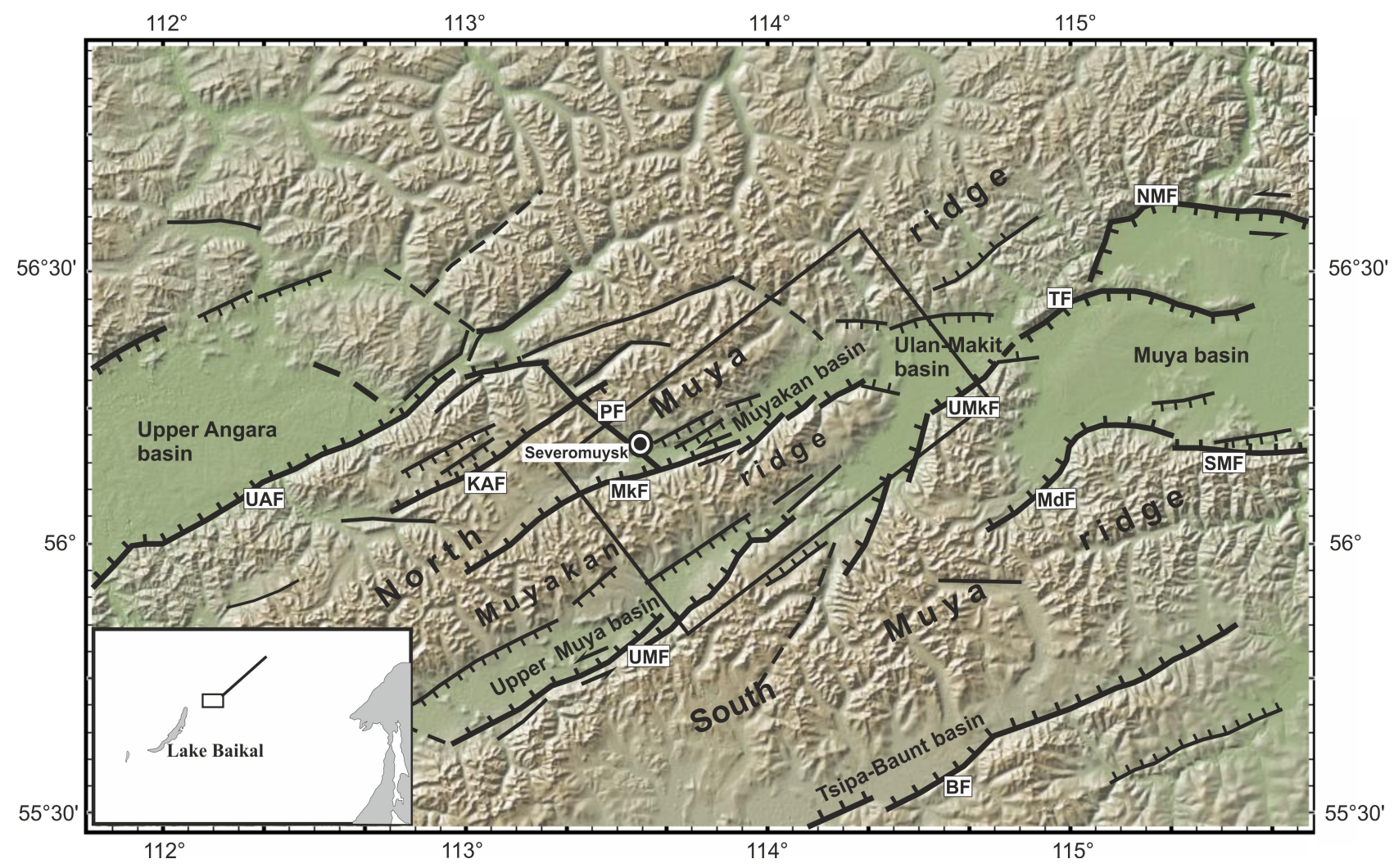

Fig. 1. Topography and active faults in North Muya region.

Thick solid (dashed) lines - active well-expressed (inferred) major normal and strike-slip faults; thin solid (dashed) lines - observed (inferred) secondary normal faults. UAF - Upper Angara fault, KAF - Kovokta-Angarakan fault, PF - Perevalny fault, MkF - Muyakan fault, UMF - Upper Muya fault, UMkF - Ulan-Makit fault, TF - Taksimo fault, NMF - North Muya fault, SMF - South Muya fault. Polygon shows the study area.

Рис. 1. Рельеф и активные разломы Северо-Муйского района.

Толстые сплошные (пунктирные) линии - установленные (предполагаемые) активные, хорошо выраженные в рельефе сбросы и сдвиги; тонкие сплошные (пунктирные) линии -второстепенные установленные (предполагаемые) сбросы. UAF - Bepхнеангарский разлом, KAF - Ковокта-Ангараканский разлом, PF - Перевальный разлом, MkF - Муяканский разлом, UMF - Bерхнемуйский разлом, UMkF - Улан-Макитский разлом, TF - Таксиминский разлом, NMF - Северомуйский разлом, SMF - Южно-Муйский разлом. Прямоугольником показан район исследований.

normal component of displacements [San'kov et al., 1991]. Fault plane solutions for small-magnitude earthquakes [Déverchère et al., 1993] show the predominance of nearly purely extension stress. The solutions for strong earthquakes show both extension and strikeslip stresses acting in the fault zone [Golenetsky, Misharina, 1978; Doser, 1991]. Some evidence from the Muyakan seismogenic paleo rupture indicated that the amplitudes of single-event vertical normal-fault displacements were as large as 6-7 m [Solonenko, Mandelbaum, 1985]. The western tip of the seismogenic dislocation is $4-5 \mathrm{~km}$ away from Severomuysk town and the eastern tunnel portal of BAM ESR. In the study area, the BAM railway goes along the Muyakan structure and intersects some of its dislocations. Obviously, the engineering-seismogeological conditions in this area are unfavorable for the railway and other manmade structures [Solonenko, Mandelbaum, 1985]. The Perevalny fault extends northwestward across the North Muya Range. The expression of this fault and its influence on the geodynamic setting vary along the fault segments. In the vicinity of Severomuysk town a low-intensity gravity step trending northwestward of the Muyakan basin and a relatively deep valley are observed in topography. This fault branch is represented by a series of normal-fault scarps along which the northeastern fault block was thrown down in the Cenozoic [San'kov et al., 1991].

\section{INTERPRETATION OF THE DIFFERENTIAL SAR INTERFEROMETRY DATA}

The processed ENVISAT/ASAR and ALOS/PALSAR data are presented in Tables 1 and 2 .

In order to reduce topographic effects on remotely 


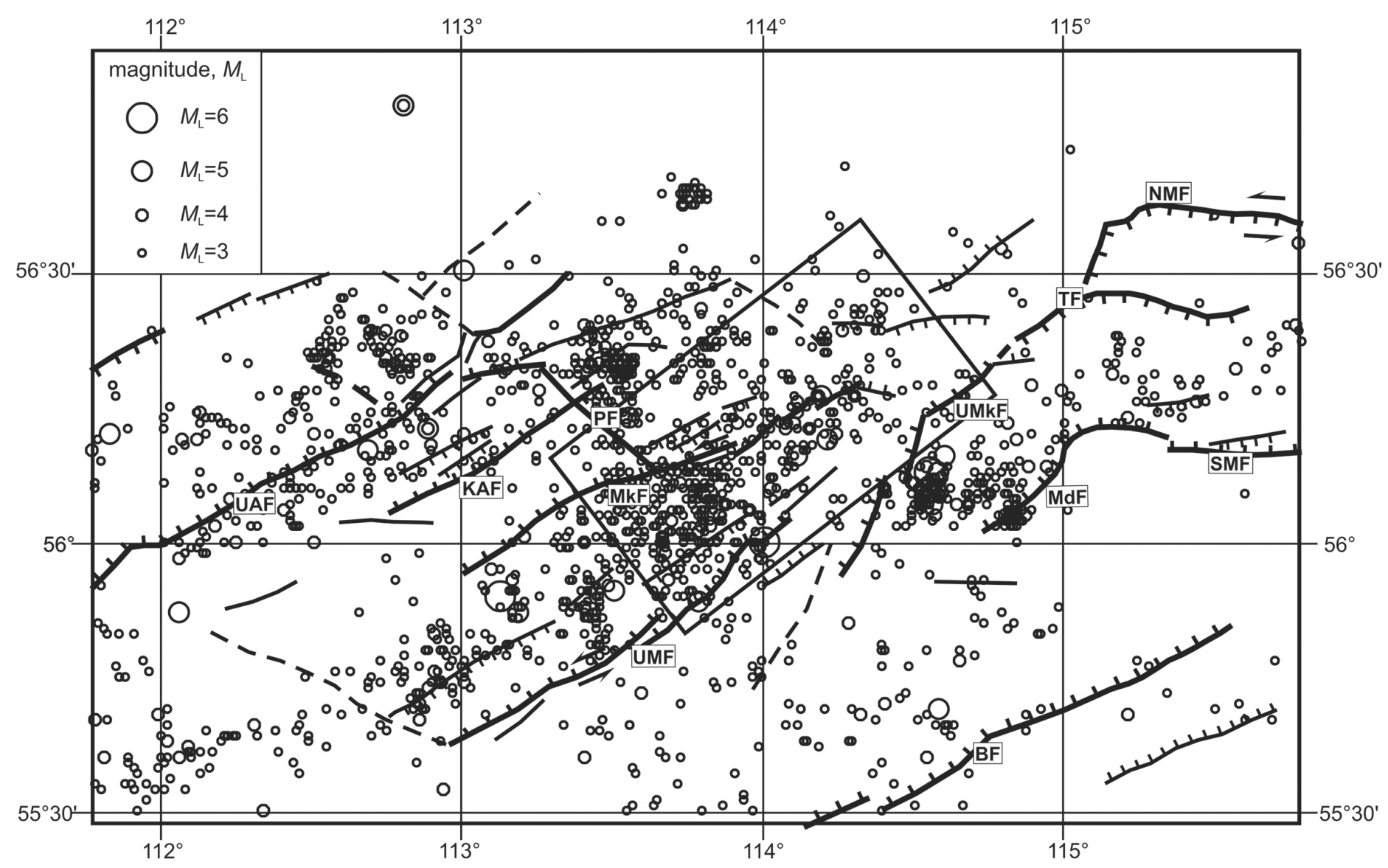

Fig. 2. Epicenters field of earthquakes M>2.5 of North Muya region recorded between 1962 and 2012.

Рис. 2. Карта эпицентров землетрясений Северо-Муйского района с М>2.5 за 1962-2012 гг.

sensed data and obtain acceptable interferometric results, we used image pairs with small perpendicular baselines $(B \perp)$ (the projection of the satellite distance on the line perpendicular to the LOS and the vector of the instantaneous velocity of a satellite). Such an approach, complemented with subtracting a Digital Elevation Model, makes it possible to observe deformations even in mountainous terrain not impacted by radar shadowing.

A general recommendation to mitigate temporal decorrelation is careful selection of image pairs based on short temporal baselines. However, in some cases, a strong correlation is observed for several years [Klees, Massonnet, 1999].

Endogenous linear-localized and areal deformations. All interferograms derived from the ENVISAT images (see Table 1) show a significant effect of temporal decorrelation due to changes in the numerous bogs in the valleys and the dissected topography. Nevertheless, four areas of high coherence are revealed in the same parts of three image pairs $(13 / 01 / 2004-$ 08/03/2005, 16/05/2004-18/09/2005 and 17/02/ 2004-17/01/2006) (Fig. 3, all interferograms are given in SAR geometry). For our analysis, we have selected the pair with a $3 \mathrm{~m}$ perpendicular baseline $(13 / 01 / 2004-08 / 03 / 2005)$ so that the relief influence on interferometric phase difference is minimal.

The ENVISAT/ASAR data show that in the zone of dynamic influence of the Muyakan fault there are two types of endogenous deformations, which may be determined as tectonic linear localized and areal. The linear localized deformations are confined directly to the fault plane (Fig. 3) traced at the foot of the Muyakan Range scarp. The maximum length of the continual linear deformation observed in the southern boarders of the Muyakan basin is $30 \mathrm{~km}$ with a width of about $1.5 \mathrm{~km}$. Such dimensions of the anomalies exclude an exogenous origin of these deformations. In 2004-2006, seismic activity of the fault zone was rather low. No earthquake with $M l>3.5$ occurred within the study area during this period. Therefore, we cannot attribute these deformations to the accumulation and release of elastic stresses by seismic events. We suppose that the deformations along the Muyakan fault are similar to socalled parametric deformations that were first recognized, described and referred to as very intensive in [Kuzmin, 2013]. This type of deformations is geodetically observed in active fault zones located both in 
$\mathrm{T}$ a b l e 1. ENVISAT interferometric pairs

Т а б л и ц а 1. Использованные пары снимков ENVISAT

\begin{tabular}{|c|c|c|c|}
\hline $\begin{array}{l}\text { Master image date } \\
(\mathrm{dd} / \mathrm{mm} / \text { yyyy })\end{array}$ & $\begin{array}{l}\text { Slave image date } \\
\text { (dd/mm/yyyy) }\end{array}$ & $\begin{array}{l}\text { Normal baseline } \\
(\mathrm{B} \perp, \mathrm{m})\end{array}$ & Comments \\
\hline \multicolumn{4}{|l|}{ Track 204} \\
\hline $13 / 01 / 2004$ & $08 / 03 / 2005$ & 3 & $\begin{array}{l}\text { The interferogram demonstrates a good coherence in the } \\
\text { area of expected deformation (see Fig. 2) }\end{array}$ \\
\hline $17 / 02 / 2004$ & $17 / 01 / 2006$ & 200 & $\begin{array}{l}\text { The interferogram demonstrates a good coherence in the } \\
\text { area of expected deformation (see Fig. 2) }\end{array}$ \\
\hline \multicolumn{4}{|l|}{ Track 247} \\
\hline $12 / 12 / 2003$ & $20 / 02 / 2004$ & 243 & Residual topographic phase in the mountainous areas \\
\hline $12 / 12 / 2003$ & $30 / 04 / 2004$ & 188 & The coherence is lost Singular \\
\hline $12 / 12 / 2003$ & $20 / 05 / 2005$ & 248 & The coherence is lost \\
\hline $20 / 02 / 2004$ & $30 / 04 / 2004$ & 55 & The coherence is lost \\
\hline $11 / 03 / 2005$ & $02 / 09 / 2005$ & 153 & The coherence is lost \\
\hline \multicolumn{4}{|l|}{ Track 476} \\
\hline $07 / 03 / 2004$ & $01 / 05 / 2005$ & 324 & Low coherence \\
\hline $16 / 05 / 2004$ & $18 / 09 / 2005$ & 226 & $\begin{array}{l}\text { The interferogram demonstrates a good coherence in the } \\
\text { area of expected deformation; some displacements are de- } \\
\text { tected (see Fig. 2) }\end{array}$ \\
\hline $23 / 10 / 2005$ & $27 / 11 / 2005$ & 178 & $\begin{array}{l}\text { The coherence is rather low; a lot of noisy areas in the } \\
\text { mountains }\end{array}$ \\
\hline
\end{tabular}

mobile areas and on the platforms. The parametric deformation rates are as high as $10^{-5}$.

Most of these deformations, not followed by seismicity, are observed directly in the fault zones. The authors relate the origin of these deformations to the change in parameters of the medium inside the fault zone, near its major fault plane (as evidenced by gauge zones and the surrounding fractured medium).

The areal deformations discovered near the tip of the Muyakan fault (Fig. 3) on the NE closure of the Muyakan basin and the western side of the Ulan-Makit basin cannot be directly attributed to seismogenic motions either. The areal deformation pattern corresponds to the stress distribution pattern at the tip of the left-lateral strike-slip in the elastic medium [Osokina, 2010]. The eastern tip of the northern side of the fault is associated with an area of crustal extension and surface subsidence. In the southeastern part of the fault, there is an area of crustal compression and surface uplifting. These data correlate with the kinematic type of the Muyakan fault, which is determined by the geological data [San'kov et al., 1991] as normal fault with leftlateral strike-slip component.

Landslide. Since the 1990s, a landslide has been developing at the Baikal-Amur railway segment at a distance of located several kilometers from the North Muya tunnel (Kazankan station, Severomuysk town, coordinates 56.1N 113.8E). The leveling and

\section{$\mathrm{T}$ a b l e 2. PALSAR interferometric pairs}

T а б л и ц а 2. Использованные пары снимков PALSAR

\begin{tabular}{|c|c|c|c|}
\hline $\begin{array}{l}\text { Master image date } \\
(\mathrm{dd} / \mathrm{mm} / \text { yyyy) }\end{array}$ & $\begin{array}{l}\text { Slave image date } \\
\text { (dd/mm/yyyy) }\end{array}$ & $\begin{array}{l}\text { Normal baseline } \\
(B \perp, m)\end{array}$ & Comments \\
\hline $17 / 01 / 2009$ & $12 / 01 / 2007$ & 256 & $\begin{array}{l}\text { Sufficient coherence near Kazankan landslide; displacements } \\
\text { are detected }\end{array}$ \\
\hline $23 / 07 / 2010$ & $15 / 10 / 2007$ & 844 & Low coherence \\
\hline $23 / 01 / 2011$ & $01 / 03 / 2008$ & 864 & $\begin{array}{l}\text { Sufficient coherence near Kazankan landslide; displacements } \\
\text { are detected }\end{array}$ \\
\hline $04 / 03 / 2009$ & $17 / 01 / 2009$ & 501 & $\begin{array}{l}\text { Sufficient coherence near Kazankan landslide; the area is } \\
\text { stable. DEM for interferogram flattening is created from the } \\
\text { pair }\end{array}$ \\
\hline
\end{tabular}



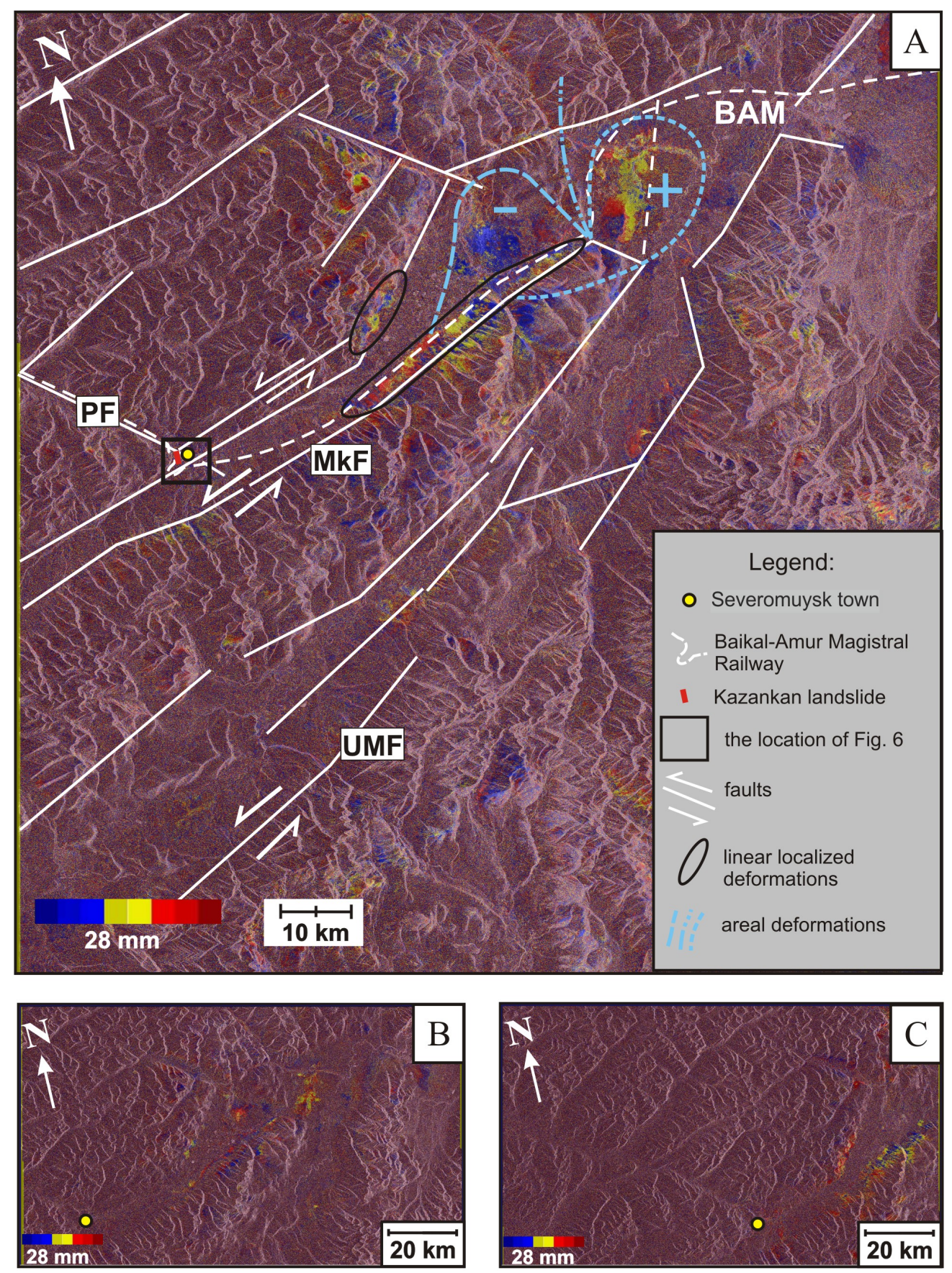

Fig. 3. Wrapped interferograms imposed on the amplitude images.

$A, B, C$ - interferograms derived from pairs 13/01/2004-08/03/2005 (A), 17/02/2004-17/01/2006 (B), and 16/05/2004-18/09/2005 (C). PF - Perevalny fault, MkF - Muyakan fault, UMF - Upper Muya fault.

Рис. 3. Интерферограммы с неразвернутой фазой, наложенные на амплитудные снимки.

$A, B, C$ - интерферограммы, полученные для пар снимков 13/01/2004-08/03/2005 (A), 17/02/2004-17/01/2006 (В), и 16/05/ 2004-18/09/2005 (C). PF - Перевальный разлом, MkF - Муяканский разлом, UMF - Верхнемуйский разлом.

GPS geodetic measurements (Irkutskzheldorproekt, 2002-2003) showed the rail track displacement at a rate up to $2 \mathrm{~cm} /$ month along the slope in the slip area.

The Kazankan landslide is of concern because it has a potential threat to the railway facility and operations. According to [Trzhtsinsky et al., 2004], landsliding in this area was triggered by railroad cutting operations and permafrost degradation and increased due to excessive loading of the slope.

Obviously, the influence of seismic and tectonic activity on rock disintegration and landslide development in this area is a source of further concern, as the recent 


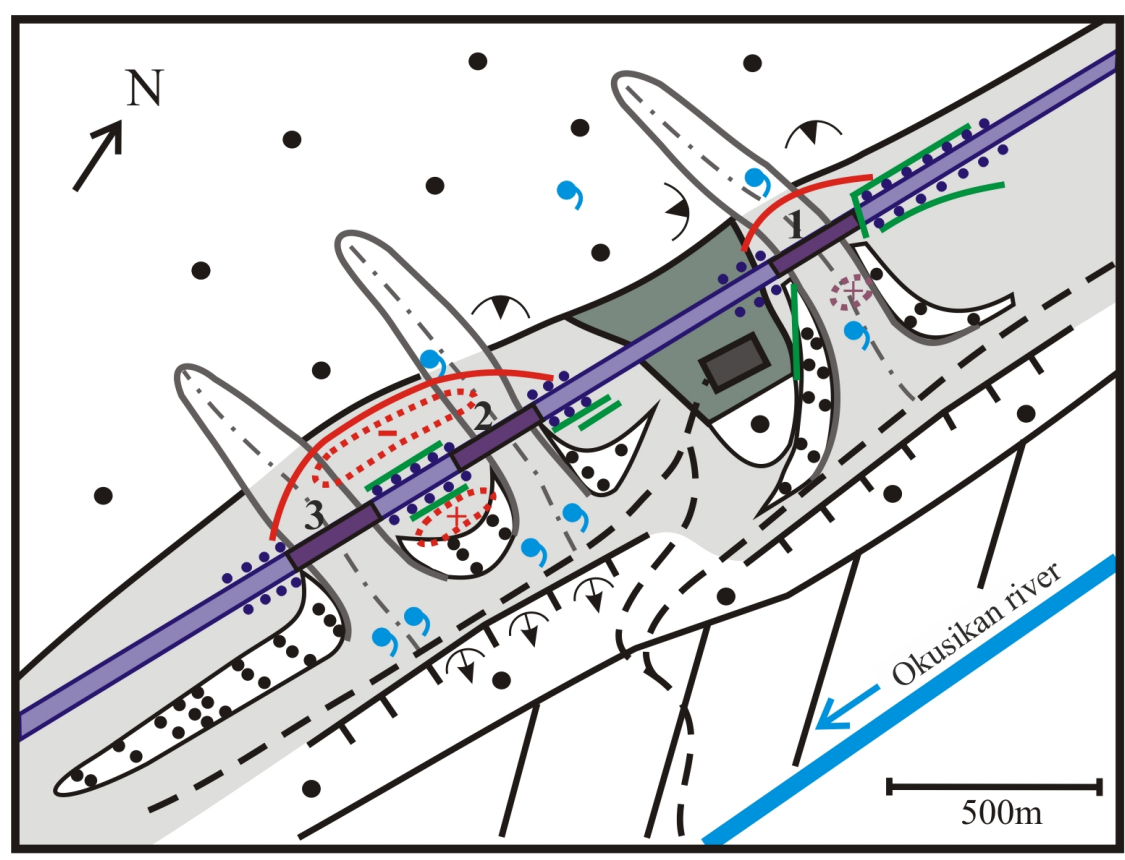

\begin{tabular}{|c|c|c|c|}
\hline - & Natural slope & & Okusikan river \\
\hline & $\begin{array}{l}\text { Accumulation terrace } \\
\text { of the Okusikan River }\end{array}$ & & $\begin{array}{l}\text { Vertical deformation amplitudes } \\
\text { measured using GPS-geodesy }\end{array}$ \\
\hline & Moranic remnant & ) & Spring \\
\hline & Railway construction site & & Steep scarps \\
\hline & Steep slopes & & Ravines with steep thalwegs \\
\hline & Station building & & Landslide cirque \\
\hline & Railway & & Sluff \\
\hline & Railway bridge & $\gamma$ & Small landslides \\
\hline & Roads & & Fractures in roadbed and embankme \\
\hline$\bullet \bullet$ & $\begin{array}{l}\text { Seasonal congealing } \\
\text { constructions }\end{array}$ & 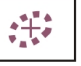 & $\begin{array}{l}\text { Vertical deformation amplitudes } \\
\text { measured using surface laser scanning }\end{array}$ \\
\hline
\end{tabular}

Fig. 4. Sketch showing the slope and roadbed conditions near Kazankan station (after [Trzhtsinsky et al., 2004] and [Zalutsky, 2007] with additions).

Рис. 4. Схема, показывающая склоновые и инженерные условия вблизи станции Казанкан (составлена по данным [Trzhtsinsky et al., 2004] и [Zalutsky, 2007]).

studies have shown that the Kazankan landslide develops in the zone of influence of seismically active Muyakan and Perevalny faults.

In [Trzhtsinskii et al., 2004], the sketch shows the slope and roadbed conditions near Kazankan station on the basis of the GPS-geodetic and ground surveys and suggests soil tilting in the upland zone and uplifting near the second and third bridges (see labels 2 and 3 in Fig. 4).
The surface laser scanning conducted in 2005 [Zalutsky, 2007; Kartashov, Zalutsky, 2009] shows an uplift near the first bridge (see lable 1 in Fig. 4). The rock mass movements led to deformation of the road bed [Kartashov, Zalutsky, 2009] and caused slippage of the engineering constructions (Fig. 5). To protect the railroad from continuous deformations, the railroad tracks had been already relocated to the upland zone [Kartashov, Zalutsky, 2009]. 

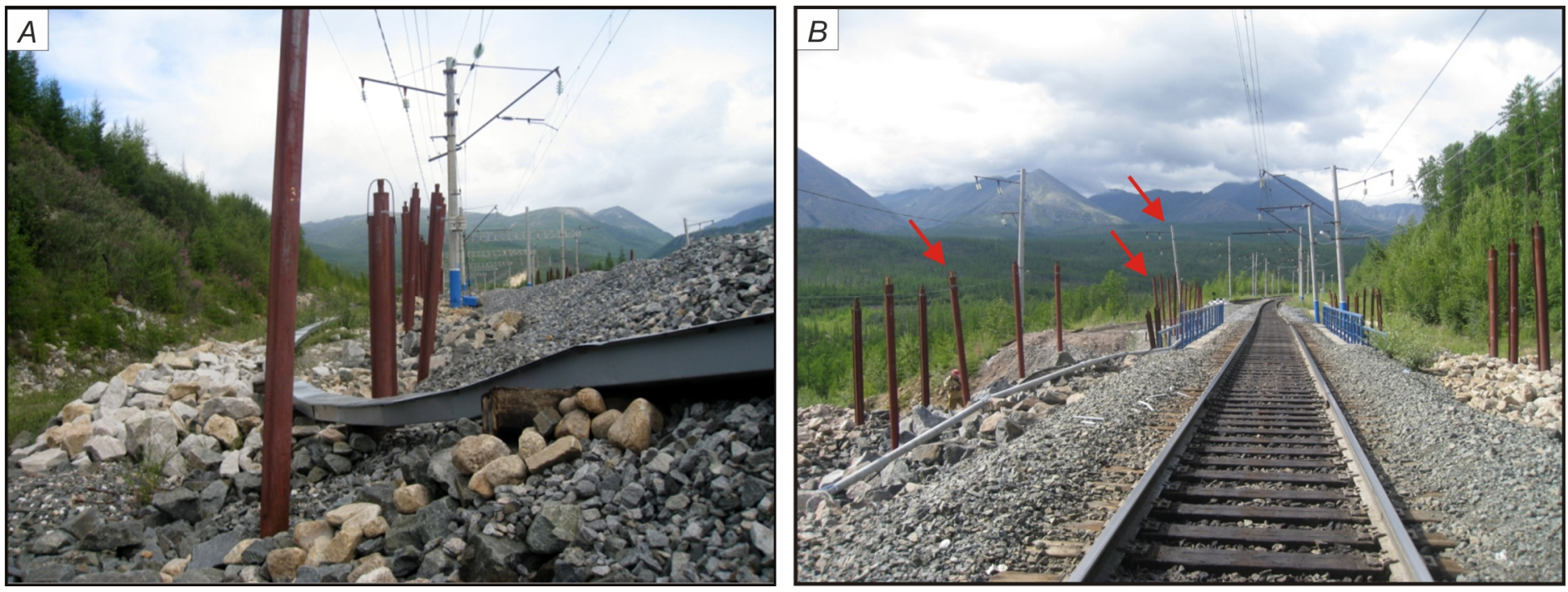

Fig. 5. An example of tilted vertical constructions near Kazankan station. Red arrows show seasonal congealing constructions and the electric column inclined due to mass movement (area near the first bridge, labelled 1 in fig. 4 ) (photo by the railroad staff, 2010).

Рис. 5. Пример наклона вертикальных конструкций вблизи железнодорожной станции Казанкан. Красные стрелки показывают участки сезонного промерзания конструкции и опоры линии электропередачи, наклоненные вследствие движения грунтовых масс (район возле первого моста, обозначенный 1 на рис. 4) (фото персонала железной дороги, 2010).

We have studied the landslide development near Kazankan station with the use of the ascending ALOS/ PALSAR images (see Table 2) because during the ascending portion of the orbit, the expected displacement direction is opposed to the satellite motion. Unfortunately, none of the available ENVISAT/ASAR images (including images from the descending orbit of ENVISAT) can be used to study the Kazankan landslide, because the satellite orbit is parallel to the direction of the landslide displacement.

On the contrary, the ALOS/PALSAR scenes acquired from the ascending part of the orbit are acceptable for interferometric measurements of the surface displacements in the study area.

Regardless of wintertime imaging and long intervals between the surveys, we used the ALOS/PALSAR radar image pairs of 17/01/2009-12/01/2007 and 23/01/2011-01/03/2008 and derived good quality interferograms for analysis of surface changes in the study area (Fig. 6). Locations of deformations in the interferograms coincide almost exactly with those at the three bridges to the west of Severomuysk town (see labels 1, 2, and 3 in Fig. 6) wherein significant displacements were detected by the ground surveys, as mentioned above [Trzhtsinsky et al., 2004; Zalutsky, 2007]. Phase difference examination gives the estimated LOS displacements of $61 \mathrm{~mm}$ for the pair $17 / 01 / 2009-12 / 01 / 2007$, and $86 \mathrm{~mm}$ for the pair $23 / 01 / 2011-01 / 03 / 2008$. In the landslide motion di- rection (see red arrows in Fig. 6, $A$ and $B$ ), the estimated displacements amount to $80 \mathrm{~mm}$ and $112 \mathrm{~mm}$, respectively. Contributions of the first and second pairs to the monthly surface displacement are 3.3 and 3.2 $\mathrm{mm}$, respectfully.

These values are seemingly underestimated in comparison with the actual ground measurements because we can observe only relative displacements in the images (in this case, the slope motion with respect to the bridges). The areas undergoing uplifting, possibly related to slope failure, have been found below the railway track at the second and third bridges. Geologically, the growth of landslide is evidenced by extrusion along the cylindrical slip plane with negative displacement in the cirque area and positive displacement in the frontal part [Trzhtsinsky et al., 2004; Zalutsky, 2007], which look like small bright areas at the landslide border to the east of bridge 3 in Fig. $6, A$ and $B$. The areas near the bridges are subsiding (dark spots near bridges 2 and 3 in Fig. 6, $A$, and bridge 3 in Fig. 6, $B$ ), probably due to solifluction which is common in the study area. Previously unknown landslide propagation along the slope has been found between the first and the second bridges (dark spots above the slope from the railway). Additional investigations and monitoring are required to clarify the mechanism of the landslide propagation. In our opinion, widening of the landslide circus, as well as changes in movements rates of the landslide body in both space and time may cause this phenomena. 

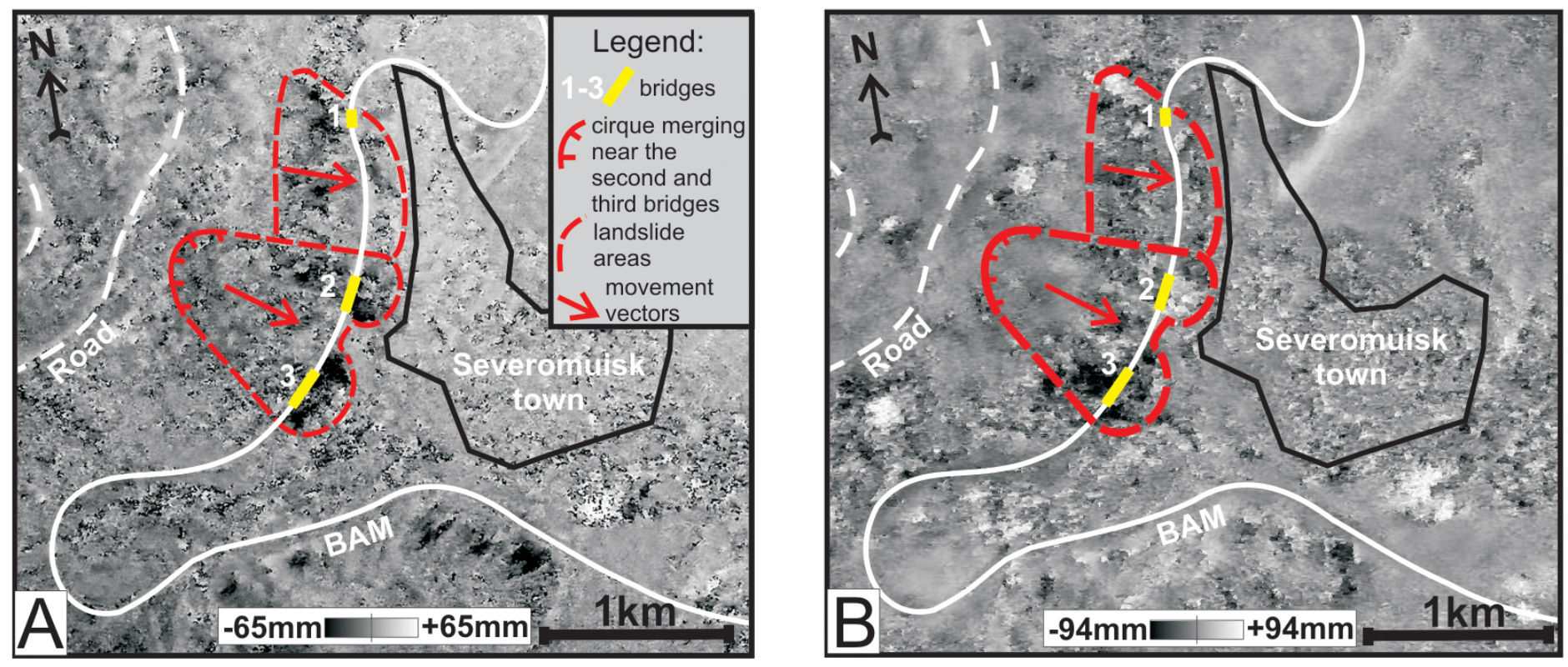

Fig. 6. The deformation pattern derived from unwrapped interferograms. $A$ - the pair $17 / 01 / 2009-12 / 01 / 2007 ; B-$ the pair 23/01/2011-01/03/2008.

Рис. 6. Деформационная схема, составленная из развернутых интерферограмм. $A$ - пара 17/01/2009-12/01/2007; B - пара 23/01/2011-01/03/2008.

Our analysis confirms that the measures taken to strengthen the slope and the railway embankment did not stop the slope from degradation and sliding. In fact, there is an urgent need to continue the slope strengthening works or to take measures to relocate the problem segment of the railway.

We intend to continue our studies and, based on analysis of displacement vectors, geological and onland geodetical data, model the slip growth in a more detail with a time pattern of displacements.

\section{CONCLUSIONS}

The deformations near the Upper Muya interbasin link of the northeastern segment of the Baikal rift system have been studied by the differential SAR interferometry method, and new data on the present-day ground-surface displacements of differing origin have been obtained. Two types of deformations, tectoniclinear localized and areal, are distinguished in the zone of dynamic influence of the Muyakan fault. The deformations observed directly in-situ in the fault zone may be referred to as parametric, associated with changes in the state of the medium in the fault zone. The spatial pattern of deformation corresponds to that of stress distribution at the tip of the left-lateral strike-slip fault in the elastic medium.

The first investigations based on the SAR data for the area near Severomuysk town have shown that
ALOS/PALSAR images are useful for monitoring the landslide motions in the immediate vicinity of Kazankan station of the BAM ESR. The soil slip continues to grow, and the engineering works performed to stabilize the slope are evidently insufficient to protect the railway tracks and facilities from damage. The cirques between the first and second bridges are now merging, and the landslide may thus be activated and become a major threat to the railway facilities and operations.

Therefore, the deformations in the Muyakan fault zone are the current serious hazard to the structures and facilities of the Baikal-Amur Railway. Our study have confirmed that the SAR interferometry method has high potential for both studying the past events and monitoring of the evolving processes in this region.

The ALOS-1 PALSAR mission was completed in 2011. In 2014, the Japan Aerospace Exploration Agency (JAXA) launched the new advanced mission ALOS-2 PALSAR2 for precise land coverage observation and continues to fulfill its commitment to provide the international science community with L-band SAR data. We plan to continue our research with the use of new satellite data to address the issues of surface deformations near the Baikal-Amur railway.

\section{ACKNOWLEDGEMENTS}

The authors express their gratitude to ITT Company and its Russian distributor, SOVZOND Company for Temporary SARscape License, to European Space 
Agency (ESA) for ENVISAT/ASAR radar images obtained as part of Cat-1 6320 project, and to the Japan Aerospace Exploration Agency (JAXA) for ALOS/
PALSAR radar images used in this study. The computations were performed using the TU Delft orbit data and SRTM digital elevation models.

\section{REFERENCES}

Cumming I., Wong F., 2005. Digital Processing of Synthetic Aperture Radar Data: Algorithms and Implementation. Artech House Publishers, New York, 632 p.

Déverchère J., Houdry F., Solonenko N.V., Solonenko A.V., San'kov V.A., 1993. Seismicity, active faults and stress fields of the North Muya region, Baikal rift: New insights on the rheology of extended continental lithosphere. Journal of Geophysical Research 98 (B11), 19895-19912. http://dx.doi.org/10.1029/93JB01429.

Doser D.I., 1991. Faulting within the eastern Baikal rift as characterized by earthquake studies. Tectonophysics 196 (1-2), 109-139. http://dx.doi.org/10.1016/0040-1951(91)90292-Z.

Elachi C., van Zyl J., 2006. Introduction to the Physics and Techniques of Remote Sensing. Second edition. John Wiley \& Sons, New York, $616 \mathrm{p}$.

Franceschetti G., Lanari R., 1999. Synthetic Aperture Radar Processing. CRC Press, New York, 328 p.

Gabriel A.K., Goldstein R.M., 1988. Crossed orbit interferometry: theory and experimental results from SIR-B. International Journal of Remote Sensing 9 (5), 857-872. http://dx.doi.org/10.1080/01431168808954901.

Gabriel A.K., Goldstein R.M., Zebker H.A., 1989. Mapping Small Elevation Changes Over Large Areas: Differential Radar Interferometry. Journal of Geophysical Research 94 (B7), 9183-9191. http://dx.doi.org/10.1029/JB094iB07p09 183.

Goldstein R.M., Engelhardt H., Kamb B., Frolich R.M., 1993. Satellite radar interferometry for monitoring ice sheet motion: Application to an Antarctic ice stream. Science 262 (5139), 1525-1530. http://dx.doi.org/10.1126/science. 262.5139 .1525$.

Golenetsky S.I., Misharina L.A., 1978. Seismisity and earthquake focal mechanisms in the Baikal rift zone. Tectonophysics 45 (1), 71-86. http://dx.doi.org/10.1016/0040-1951(78)90225-1.

Hanssen R.F., 2001. Radar Interferometry. Data Interpretation and Error Analysis. Delft University of Technology, Delft, Netherlands, 308 p.

Houdry-Lémont, F., 1994. Mécanismes de l'Extension Continentale dans le Rift Nord-Baikal, Siberie: Contrantes des Données d'Imagerie SPOT, de Terrain, de Sismologie et de Gravimétrie. Thése de doctorat de Université Pierre et Marie Curie Paris 6. Laboratoire de Géodynamique Sous-Marine, Obsernatoire Océanologique de Villefranche-surMer, $345 \mathrm{p}$.

Kartashov V.A., Zalutsky V.T., 2009 Some geodetic technologies of explorations on the East-Siberian railway. In: Innovative technologies for an efficient geospatial management of Earth resources. Proceedings of FIG and SSGA Workshop, Russia, Irkutsk-Listvyanka, 26 July 2009. Available from: https://www.fig.net/resources/ proceedings/2009/lakebaikal_2009_comm6/ppt/kartashov_zalutsky_ppt.pdf.

Klees R., Massonnet D., 1999. Deformation measurements using SAR interferometry: potential and limitations. Geologie en Mijnbouw 77 (2), 161-176. http://dx.doi.org/10.1023/A:1003594502801.

Kuzmin Yu.O., 2013. Recent geodynamics of the faults and paradoxes of the rates of deformation. Izvestiya, Physics of the Solid Earth 49 (5), 626-642. http://dx.doi.org/10.1134/S1069351313050029.

Massonnet D., Rabaute T., 1993. Radar interferometry: limits and potential. IEEE Transactions on Geoscience and Remote Sensing 31 (2), 455-464. http://dx.doi.org/10.1109/36.214922.

Osokina D.N., 2010. Fields of local stresses of different levels and second order fractures close to the off of a strike slip fault. Izvestiya, Physics of the Solid Earth 46 (5), 419-432. http://dx.doi.org/10.1134/S1069351310050071.

Peltzer G., Hudnut K.W., Feigl K.L., 1994. Analysis of coseismic surface displacement gradients using radar interferometry: New insights into the Landers earthquake. Journal of Geophysical Research 99 (B11), 21971-21981. http://dx.doi.org/10.1029/94JB01888.

Petit C., Meyer B., Gunnell Y., Jolivet M., San'kov V., Strak V., Gonga-Saholiariliva N., 2009. The height of faceted spurs, a proxy for determining long-term throw rates on normal faults: evidence from the North Baikal Rift System, Siberia. Tectonics 28 (6), TC6010. http://dx.doi.org/10.1029/2009TC002555.

San'kov V., Déverchère J., Gaudemer Y., Houdry F., Filippov A., 2000. Geometry and rate of faulting in the North Baikal Rift, Siberia. Tectonics 19 (4) 707-722. http://dx.doi.org/10.1029/2000TC900012.

San'kov V.A., Dneprovsky Yu.I., Kovalenko S.N., Bornyakov S.A., Gileva N.A., Gorbunova N.G., 1991. Faults and Seismicity of the North Muya Geodynamic Test Area. Nauka, Novosibirsk, 111 p. (in Russian) [Саньков В.А., Днепровский Ю.И., Коваленко С.Н., Борняков С.А., Гилева Н.А., Горбунова Н.Г. Разломы и сейсмичность Северо-Муйского геодинамического полигона. Новосибирск: Наука, 1991. 111 с.]. 
Sandwell D.T., Myer D., Mellors R., Shimada M., Brooks B., Foster J., 2008. Accuracy and resolution of ALOS interferometry: vector deformation maps of the Father's Day intrusion at Kilauea. IEEE Transactions on Geoscience and Remote Sensing 46 (11), 3524-3534. http://dx.doi.org/10.1109/TGRS.2008.2000634.

Sherman S.I., Levi K.G., Bornyakov S.A., 1980. Block tectonics of the Muyakan-Angarakan interfluve area and some seismicity problems. In: M.M. Odintsov (Ed.), Seismotectonics and Seismicity of the BAM Construction Area. Nauka, Moscow, p. 43-56 (in Russian) [Шерман С.И., Леви К.Г., Борняков С.А. Блоковая тектоника Муякан-Ангараканского междуречья и некоторые вопросы сейсмичности // Сейсмотектоника и сейсмичность района строительства БАМ. М.: Наука, 1980. С. 43-56].

Solonenko V.P., Mandelbaum M.M. (Eds.), 1985. Geology and Seismicity of the BAM Zone. Seismogeology and Seismic Zoning. Nauka, Novosibirsk, 190 p. (in Russian) [Геология и сейсмичность зоны БАМ. Сейсмогеология и сейсмическое районирование / Ред. В.П. Солоненко, М.М. Мандельбаум. Новосибирск: Наука, 1985. 190 с.].

Soloviev S.L. (Ed.), 1985. Geology and Seismicity of BAM Zone. Seismicity. Nauka, Novosibirsk, 190 p. (in Russian) [Геология и сейсмичность зоны БАМ. Сейсмичность / Ред. С.Л. Соловьев. Новосибирск: Наука, 1985. 190 с.].

Stramondo S., Chini M., Bignami C., Salvi S., Atzori S., 2011. X-, C-, and L-Band DInSAR investigation of the April 6, 2009, Abruzzi Earthquake. IEEE Geoscience and Remote Sensing Letters 8 (1), 49-53. http://dx.doi.org/10.1109/LGRS. 2010.2051015 .

Trzhtsinsky Yu.B., Kozyreva E.A., Laperdin V.K., Zalutsky V.T., Popov O.Yu., 2004. Engineering-geological features of the Kazankan segment of the BAM. In: V.I. Osipov (Ed.), Sergeev's readings, Issue 6. Engineering geology: state-of-theart and future prospects. Materials of the annual session of RAS Scientific Council on problems of Geoecology, Engineering Geology and Hydrogeology. GEOS, Moscow, p. 438-442 (in Russian) [Тржцинский Ю.Б., Козырева Е.А., Лапердин В.К., Залуцкий В.Т., Попов О.Ю. Инженерно-геологические особенности Казанканского участка БАМ // Сергеевские чтения. Вып. 6. Инженерная геология и охрана геологической среды. Современное состояние и перспективы развития. Материалы годичной сессии Научного совета РАН по проблемам геоэкологии, инженерной геологии и гидрогеологии / Ред. В.И. Осипов. М.: ГЕОС, 2004. С. 438-442].

Zalutsky V.T., 2007. Monitoring of deformations in railroad beds using surface laser scanning. In: Problems and prospects of the Russian railroad survey, design, construction and operation. Proceeding of the All-Russian Researchto-Practice Conference (Irkutsk, Russia, October 10-11, 2007). Vol. 2. Irkutsk state transport university, Irkutsk, p. 48-53 (in Russian) [Залуцкий В.T. Мониторинг деформаций земляного полотна железных дорог с помощью наземного лазерного сканирования // Проблемы и перспективы изысканий, проектирования, строительства и эксплуатации Российских железных дорог: Материалы Всероссийской научно-практической конференции (Иркутск, 10-11 октября 2007 г.). Иркутск: ИрГУПС, 2007. Т. 2. С. 48-53].

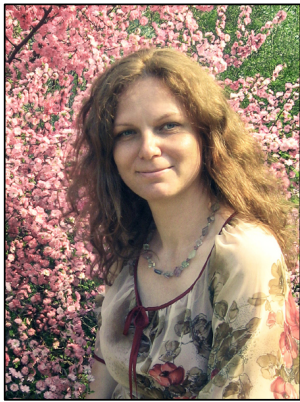

Lebedeva, Marina A., Junior Researcher

Institute of the Earth's Crust, Siberian Branch of RAS

128 Lermontov street, Irkutsk 664033, Russia

Tel.: +7(3952)429534; \ e-mail: lebedeva@crust.irk.ru

Лебедева Марина Анатольевна, м.н.с.

Институт земной коры СО РАН

664033, Иркутск, ул. Лермонтова, 128, Россия

Тел.: (3952)429534; \ e-mail: lebedeva@crust.irk.ru

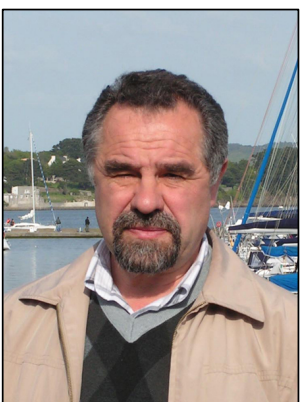

Sankov, Vladimir A., Candidate of Geology and Mineralogy, Head of Laboratory Institute of the Earth's Crust, Siberian Branch of RAS

128 Lermontov street, Irkutsk 664033, Russia

Tel. +7(3952)427903; e-mail: sankov@crust.irk.ru

Саньков Владимир Анатольевич, канд. геол.-мин. наук, зав. лабораторией

Институт земной коры СО РАН

664033, Иркутск, ул. Лермонтова, 128, Россия

Тел. (3952)427903; e-mail: sankov@crust.irk.ru 


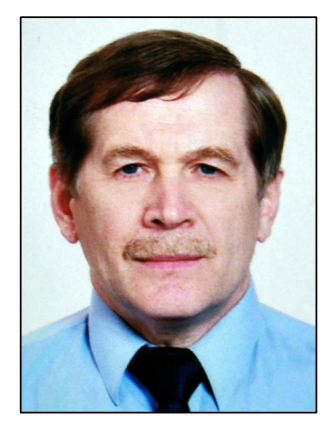

Zakharov, Aleksandr I., Doctor of Physics and Mathematics

Fryazino Branch of V.A. Kotel'nikov Institute of Radioengineering and Electronics of RAS

1 Vvedensky square, Moscow region, Fryazino 141190, Russia

e-mail: aizakhar@sunclass.ire.rssi.ru

Захаров Александр Иванович, докт. физ.-мат. наук

Фрязинский филиал Института радиотехники и электроники им. В.А. Котельникова РАН 141190, Московская область, Фрязино, пл. Введенского, 1, Россия

e-mail: aizakhar@sunclass.ire.rssi.ru

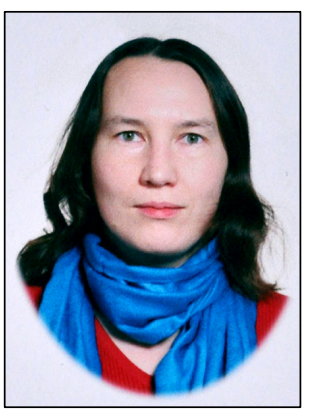

Zakharova, Ludmila N., Candidate of Physics and Mathematics

Fryazino Branch of V.A. Kotel'nikov Institute of Radioengineering and Electronics of RAS

1 Vvedensky square, Moscow region, Fryazino 141190, Russia

e-mail: ludmila@sunclass.ire.rssi.ru

Захарова Людмила Николаевна, канд. физ.-мат. наук

Фрязинский филиал Института радиотехники и электроники им. В.А. Котельникова РАН 141190, Московская область, Фрязино, пл. Введенского, 1, Россия

e-mail: ludmila@sunclass.ire.rssi.ru 